\title{
V. ERRATUM
}

Au Bulletín géodésique no 53,

janvier-tévrier-mars 1937.

P. 79, ligne 2 en remontant. Au lieu de : A. Ralaulas, lire : M. Ratautas. 